\title{
Effect of ozone on colon anastomoses in rat peritonitis model ${ }^{1}$
}

\author{
Tuğrul Çakır', Arif Aslaner ${ }^{I}$, Seçkin Özgür Tekeli', Sema AvcıIII, Uğur Doğan', Feyza Tekeli' ${ }^{\mathrm{IV}}$, Hakan Soylu ${ }^{\mathrm{III}}$, Cebrail Akyüzv \\ Süleyman Koç ${ }^{\mathrm{VI}}$, İsmail Üstünel ${ }^{\mathrm{VII}}$, Necat Yılmaz ${ }^{\mathrm{VIII}}$
}

DOI: http://dx.doi.org/10.1590/S0102-865020160020000005

IMD, Chief Asssitant, Department of General Surgery, Antalya Training and Research Hospital, Antalya, Turkey. Conception, design, intellectual and scientific content of the study.

IIMD, Chief Asssitant, Department of Biochemistry, Antalya Training and Research Hospital, Antalya, Turkey. Interpretation of data.

IIIDepartment of Histology and Embryology, Akdeniz University, Antalya, Turkey. Interpretation of data.

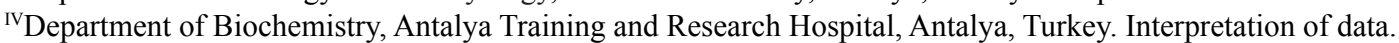

${ }^{v} \mathrm{MD}$, Department of Gastroenterology, Haydarpaşa Training and Research Hospital, Istanbul, Turkey. Interpretation of data.

${ }^{\mathrm{V} I}$ Department of General Surgery, Inonü University Faculty of Medicine, Malatya, Turkey. Scientific content of the study.

${ }^{\mathrm{VII}}$ Department of Histology and Embryology, Akdeniz University, Antalya, Turkey. Critical revision.

${ }^{\mathrm{VIII}}$ Department of Biochemistry, Antalya Training and Research Hospital, Antalya, Turkey. Critical revision.

\begin{abstract}
PURPOSE: To investigate the effects of medical ozone theraphy on the colon anastomosis of peritonitis model in rats.

METHODS: Eighteen rats were randomly assigned into three equal groups; control, cecal punctuation and colon anastomosis and ozone theraphy. Sepsis was performed with a cecal punctuation in groups 2 and 3. The medical ozone theraphy was administered intraperitonealy for three weeks in group 3 while the other rats received saline injection. At the twenty second day serum were obtained for TNF- $\alpha$ and IL-1 $\beta$, the colonic burst pressures were measured and colonic tissue samples were obtained for MDA and MPO levels. Histolopatological examination was evaluated with H\&E stain, and Ki-67, IL-1 $\beta$ and the VEGF immunostaining densities were also compared.
\end{abstract}

RESULTS: Intraperitoneal ozone administration reversed TNF- $\alpha$, IL-1 $\beta$, MDA and MPO levels and the colonic burst pressures. There was also a significant difference at immunostaining densities of histopathological examination.

CONCLUSION: Medical ozone therapy may contribute to tissue healing by affecting the proliferation and the vascularization thus has benefits on colonic anastomosis at peritonitis in rats.

Key words: Colon. Anastomosis, Surgical. Peritonitis. Rats. 


\section{Introduction}

Anastomosis is one the mostly performed surgical procedures in gastrointestinal system. Undesirable results can be achieved like anastomosis leakage. Many factors can be associated with this unwanted outcome ${ }^{1,2}$. On the presence of peritonitis, the integrity of anastomosis became so important. Many agents and procedures were studied to improve the wound healing and to diminish any anastomotic leakage in the presence of peritonitis.

Medical Ozone described as three-oxygen molecule $\left(\mathrm{O}_{3}\right)$ is used as therapeutics and found systematically effective when pathological inflammatory and immunologic processes are activated, such as wound healing. It is applied in medical therapy using a gas mixture composed of oxygen and ozone. Ozone theraphy has been found useful in the treatment of various diseases including gastroduodenal ulcers, peritonitis and colitis ${ }^{3-5}$. The concept of using ozone for healing of infected wounds, necrotic or low oxygenated tissue has been studied in orthopaedics, dentistry and skin wounds.

Furthermore the effect of $\mathrm{O}_{3}$ on colonic anastomosis at peritonitis in rats has not been studied before. The aim of this present study was to evaluate the effects of ozone theraphy on anastomotic healing in a rat peritonitis model.

\section{Methods}

The experimental procedures were reviewed and approved by Akdeniz University Local Committee on Animal Research Ethics (2014.09.18). Eighteen Wistar albino rats of male gender of weighing 250-300 g were used in this study. The rats maintained at a constant temperature $\left(22^{\circ} \mathrm{C}\right)$ with a 12 -h lightdark cycle and randomly divided into three equal groups.

\section{Experimental design and study groups}

The rats were randomly assigned into three equal groups. Group 1 was the control group receiving only physiological saline. Sepsis was performed with a cecal punctuation in groups 2 and 3 . Group 2 was the cecal punctuation and colonic anastomoses group. Group 3 was the cecal punctuation and colonic anastomoses treated with medical ozone group receiving $1 \mathrm{mg} / \mathrm{kg} /$ day medical ozone (OM-302, Ozone generator, Sedecal, Spain) intraperitoneally for three weeks at dose of $25 \mathrm{mcg} / \mathrm{ml}$. At the end of the twenty second day the rats were sacrified with decapitation and the colonic samples were obtained. The colonic anastomoses burst pressures measured and recorded. The levels of TNF- $\alpha$ and IL- $1 \beta$ from blood serum and, the levels of Malondialdeehyde (MDA) and Myeloperoxidase (MPO) from colonic tissue samples were analysed. Histopathological analysis was analyzed by an expert pathologist under a light microscope. None of the animals died during these procedures.

After six hours of fasting, anesthesia was provided by intraperioneal injection of $75 \mathrm{mg} / \mathrm{kg}$ ketamin $\mathrm{HCL}\left(\mathrm{Ketasol}^{\mathbb{Q}}\right.$, Richterpharma Ag, Wels Austria) and $10 \mathrm{mg} / \mathrm{kg}$ xylazin hydrochloride (Rompun, Bayer, Istanbul, Turkey). Antisepsis of incisional area was provided by application of povidon iodine. Then a midline laparotomy was performed using 15-no surgical scalpel. In the control group, the abdomen was closed in a running single layer with $3 / 0$ silk suture. In the other two groups, the isolated colonic segment was resected at mid-point and reanastomosed end to end with $6 / 0$ polypropylene suture. Then, the abdomen was closed in the same manner. After the smooth ending of anesthesia, the rats had free access to oral feeding at the first postoperative day. The rats received postoperative analgesia with acetaminophen (Paracetamol; Sigma-Aldrich Chemistry, Steinheim, Germany) in a dose of $50 \mathrm{mg} / \mathrm{kg} / \mathrm{d}$ by oral gavage.

Three week later, the same midline incision was opened in all the groups. After the sacrification of rats by decapitation, the blood and isolated anastomosis performed ten $\mathrm{cm}$ of colonic segment were obtained.

\section{Measurement of bursting pressures}

On the twenty second day the animals were sacrificed and the colonic anastomotic bursting pressures (BP) were measured and recorded. We resected a $10 \mathrm{~cm}$ long colonic segment, situating the anastomosis in the middle and washed it with saline solution. Two 10-Fr infusion catheters were inserted to resected flesh specimens into the proximal and distal parts and ligated with $4 / 0$ silk. After calibration of the arterial pressure system, air was injected constantly into the lumen with syringe pump at a flow rate of $50 \mathrm{~mL} / \mathrm{min}$ through the proximal catheter; meanwhile, continuous pressure was assessed on the distal catheter. Pressure assessment was performed by using an arterial pressure probe. The pressure value when the first air leak occurred in the specimen was recorded as the burst pressure. In all cases the bursting site was on the colonic anastomosis alongside.

\section{Laboratory examinations}

The plasma TNF- $\alpha$ and IL-1 $\beta$ were analysed using the enzyme-linked immunosorbent assay (ELISA) kits (YH Elisa Biosearch Laboratory, Shanghai, China). These kits were particularly selected because of their high degree of sensitivity, 
specificity and inter-assay and intra-assay precision, and due to requiring a small amount of plasma sample.

Tissue samples were homogenized with ice-cold $150 \mathrm{mM} \mathrm{KCl}$ for the determination of MDA levels. The MDA levels were assayed by monitoring thiobarbituric acid reactive substance formation as described previously ${ }^{6}$. Lipid peroxidation was expressed in terms of MDA equivalents using an extinction coefficient of $1.56 \times 10^{5} \mathrm{M}^{-1} \mathrm{~cm}^{-1}$ and results are expressed as $\mathrm{mmol} \mathrm{MDA} / \mathrm{g}$ protein.

The protein contents of various samples were determined according to the method of Bradford by using bovine serum albumin as a Standard 7 .

MPO activity was measured in tissues in a procedure similar to that documented by Hillegas et al. ${ }^{8}$. Tissue samples were homogenized in $50 \mathrm{mM}$ potassium phosphate buffer $(\mathrm{PB}, \mathrm{pH}$ 6.0 ), and centrifuged at $41.400 \mathrm{~g}$ (10min); pellets were suspended in $50 \mathrm{mM} \mathrm{PB}$ containing $0.5 \%$ hexadecyltrimethylammonium bromide (HETAB). After three freeze and thaw cycles, with sonication between cycles, the samples were centrifuged at 41.400 $\mathrm{g}$ for $10 \mathrm{~min}$. Aliquots $(0.3 \mathrm{ml})$ were added to $2.3 \mathrm{ml}$ of reaction mixture containing $50 \mathrm{mM} \mathrm{PB}$, o-dianisidine, and $20 \mathrm{mM} \mathrm{H}_{2} \mathrm{O}_{2}$ solution. One unit of enzyme activity was defined as the amount of the MPO present that caused a change in absorbance measured at $460 \mathrm{~nm}$ for $3 \mathrm{~min}$. MPO activity was expressed as $\mathrm{U} / \mathrm{g}$ tissue.

\section{Histopathological analysis}

The tissues taken from subjects of each group $(n=6)$ were fixed in $4 \%$ formalin and carried on into paraffin wax. The immunohistochemical staining was performed on sections taken after the paraffin blocking procedure at $5 \mathrm{~mm}$ thickness.

The sections were incubated overnight in $56^{\circ} \mathrm{C}$ incubator, the next morning deparafinization was performed twice with xylene for 10 minutes and dehydrated by passing through 5 minutes each in $100 \%, 90 \%, 80 \%, 70 \%$ alcohol series. The sections were washed in distilled water and washed three times for 5 minutes each in phosphate buffer. In order to eliminate antigenic masking, sections were placed in $0.01 \mathrm{M}$ citrate buffer and were boiled in a microwave oven at $750 \mathrm{~W}$ 't for $4+3$ minutes. Slides were allowed to cool at room temperature for 20 minutes.

After cooling, the sections were treated with PBS for 5 minutes. In order to remove endogenous peroxidase activity, sections were incubated for 20 minutes with $3 \%$ hydrogen peroxide (\# 18312, Sigma Aldrich). In the room temperature and nonspecific humid environment, around of the sections which were washed at PBS were drawn with the hydrophobic pencil, in order to prevent immunoglobulin (Ig) bonding treated with blocking serum (UV blocker Thermo Ultra UV Block, labvisio Corporation Ta-125UB) for 7 minutes.

More of the serum was taken and sections were incubated overnight at $+4^{\circ} \mathrm{C}$ with the primary antibody of proteins; IL$1 \beta$ (sc-7884, rabbit polyclonal IgG-Santa Cruz Biotechnology), 1: 250, VEGF (RS-152, rabbit polyclonal IgG-Santa Cruz Biotechnology), 1: 250, Ki-67 (BS-2130R, rabbit polyclonal IgGBioss antibodies) 1: 250. The isotype controls were applied to the control section instead of the primary antibody. The next day each section was washed with PBS three times for five minutes. Then, they were incubated in a humid environment for 45 minutes with biotinylated secondary antibody (biotinylated anti-rabbit $\mathrm{IgG}$ ) 1 : 500 and 20 minutes with HRP-conjugated streptavidin complex (\# 85-9043, Invitrogen) at room temperature. After both applications, washing with PBS were performed three times for five minutes. In order to see the immunostaining density, tissues were developed with Di Amino Benzidine (DAB) chromogen (\# D4168, Sigma) and washed in tap water for two minutes. Opposed staining with Mayer's hematoxylin was performed to sections and was closed with Kaiser's gelatin (\# 1.09242.0100; Merck). Sections were examined on Axioplan microscope (Zeiss, Germany) and photographed. In addition, $\mathrm{H} \& \mathrm{E}$ stain is applied to the sections of groups for morphological assessment.

\section{Image J analysis}

The immunohistochemical staining intensity of known photographs images of cross-sections performed by Axioplan microscope (Zeiss, Oberkochen, Germany) were evaluated with the Image J program (http://imagej.nih.gov/ij/). The assessment was performed with each of the five randomly selected preparations immunostained with the Ki-67, IL1- $\beta$ and VEGF. First painted (including Hematoxylin and DAB) determining the appropriate threshold level of the entire area to be masked and then density was measured only DAB positive threshold level to be masked by setting the color density of the region were measured. Staining degree was determined by dividing the DAB positive density to total staining density combination of hematoxylin and DAB and multiplying the result by 100 . As a result; average density ranging from 0 to 100 percent (\%) was expressed as the value.

\section{Statistical analysis}

Statistical analysis was performed by GraphPad Prism 3.0 (GraphPad Software, San Diego, USA). The data were expressed as mean \pm standard error of the mean (SEM). Group comparisons 
were performed with the analysis of variance (ANOVA) followed by Tukey's tests. The data related to immunohistochemical staining intensity of the groups and $\mathrm{J}$ image analysis was compared with the Student's t-test, using Sigma Plot 11.0 (Systat Software, USA). The $p<0.05$ between the groups was considered as statistically significant.

\section{Results}

\section{Results of biochemical analysis}

In the anastomosis group, TNF- $\alpha$ levels were significantly increased $(p<0.01)$ when compared to control group, while this
MTX-induced rise in serum TNF- $\alpha$ level was abolished $(\mathrm{p}<0.01)$ with ozone theraphy. Similarly IL-1 $\beta$ levels were also significantly increased in the anastomosis group $(\mathrm{p}<0.01)$, however when rats were treated with ozone. As a result both cytokines were come closer to control levels. The mean level of MDA was increased in all colonic tissues after sepsis when compared with the control group $(\mathrm{p}<0.01)$, while ozone theraphy to the sepsis anastomosis group caused a marked decrease in MDA levels $(\mathrm{p}<0.01)$. Myeloperoxidase activity was found significantly higher in the colonic tissues of the sepsis anastomosis group when compared to control group $(p<0.01)$. On the other hand, ozone theraphy decreased MPO levels of all tissues $(\mathrm{p}<0.01)$, which was found to be not different than that of the control group (Figure 1).
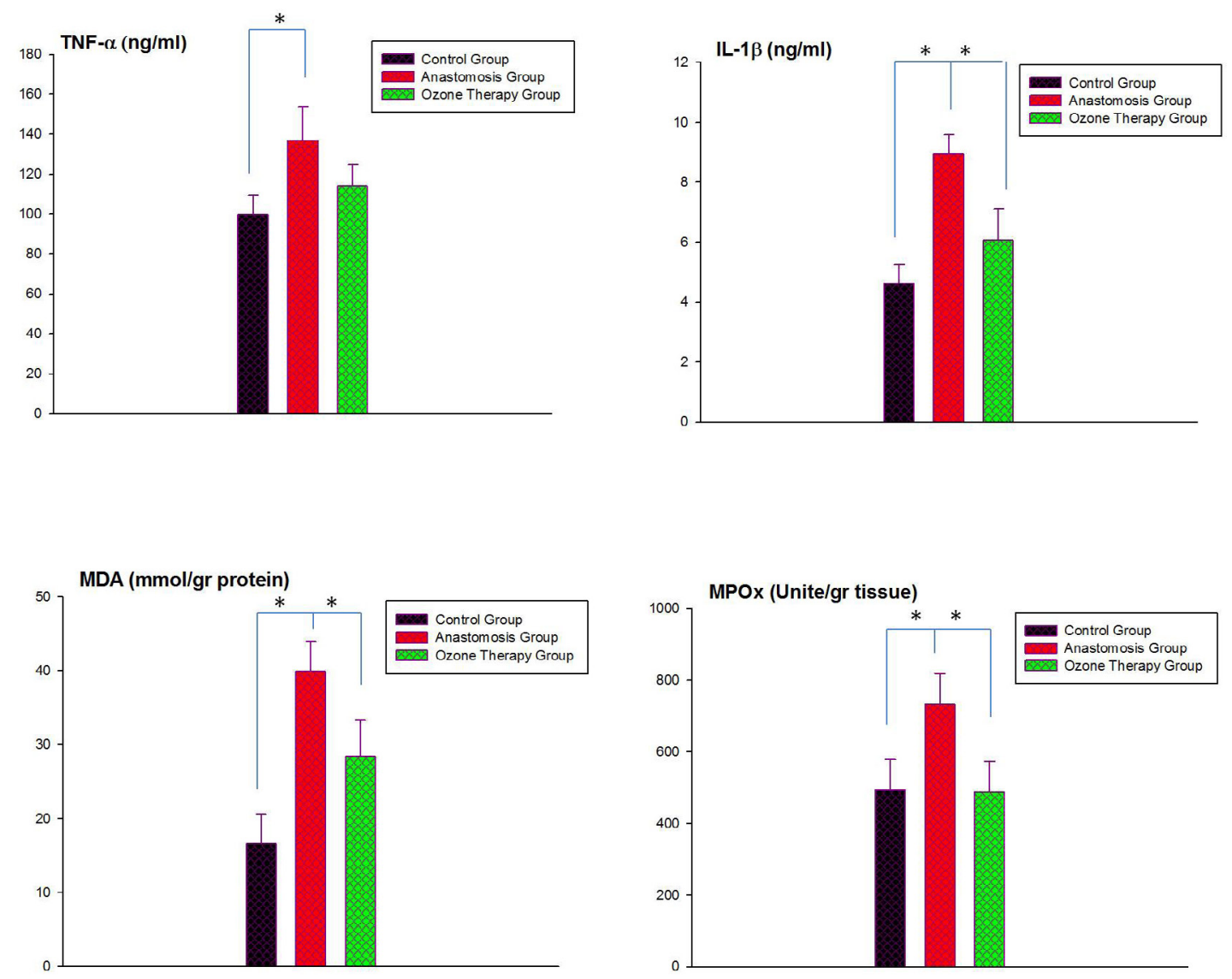

FIGURE 1 - The comparison of TNF- $\alpha$, IL-1 $\beta$, MDA and MPO levels in serum and colonic tissues of control, anastomosis and Ozone theraphy groups. Each group was consisting of 6 rats. Groups of data were compared with an analysis of variance (ANOVA) followed by Tukey's multiple comparison tests.

\section{Results of colonic anastomosis bursting pressures}

The Bursting Pressure (BP) of control, sepsis colonic anastomoses and ozone theraphy groups were $97.33 \pm 18.56 \mathrm{mmHg}$,
$76.83 \pm 14.35 \mathrm{mmHg}$ and $101.16 \pm 8.06 \mathrm{mmHg}$, respectively. There is a statistically significant difference between the results of $\mathrm{BP}$ between groups $(p<0.0216)$. Ozone treatment turned back the burst pressures into control group levels (Figure 2). 
Colonic burst pressure $(\mathrm{mm} / \mathrm{hg})$

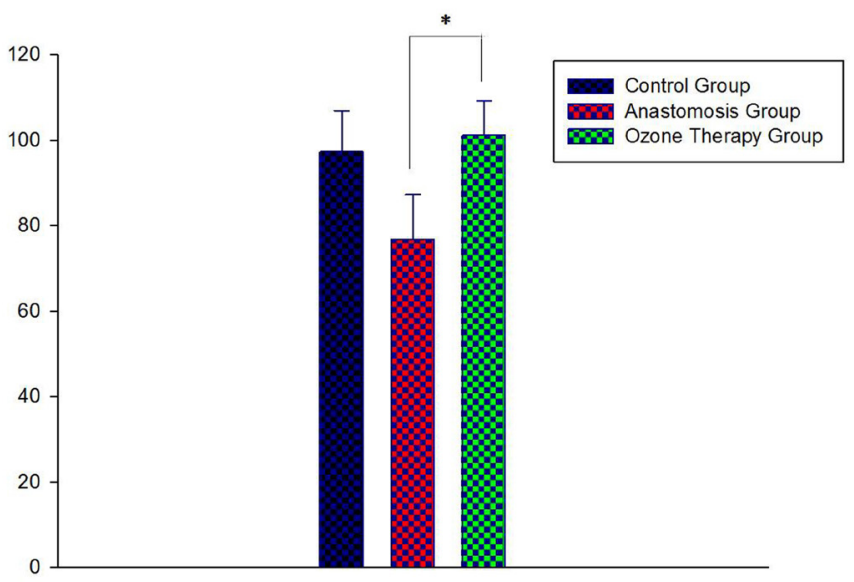

FIGURE 2 - Colonic burst pressure levels $(\mathrm{mmHg})$ in the tissues of control, colonic anastomoses and ozone theraphy groups.

\section{Effects of ozone therapy on histopathologic values}

VEGF staining intensity of the sepsis anastomosis group, after ozone therapy, particularly an increase was observed in the structure of the glandular areas neighboring to lumen (L-arrows). According to the results of the statistical analysis a significant difference on immunostaining densities were observed between the control-anastomosis groups and anastomosis-ozone therapy group (Figure 3, $\mathrm{p}<0.05$ ).

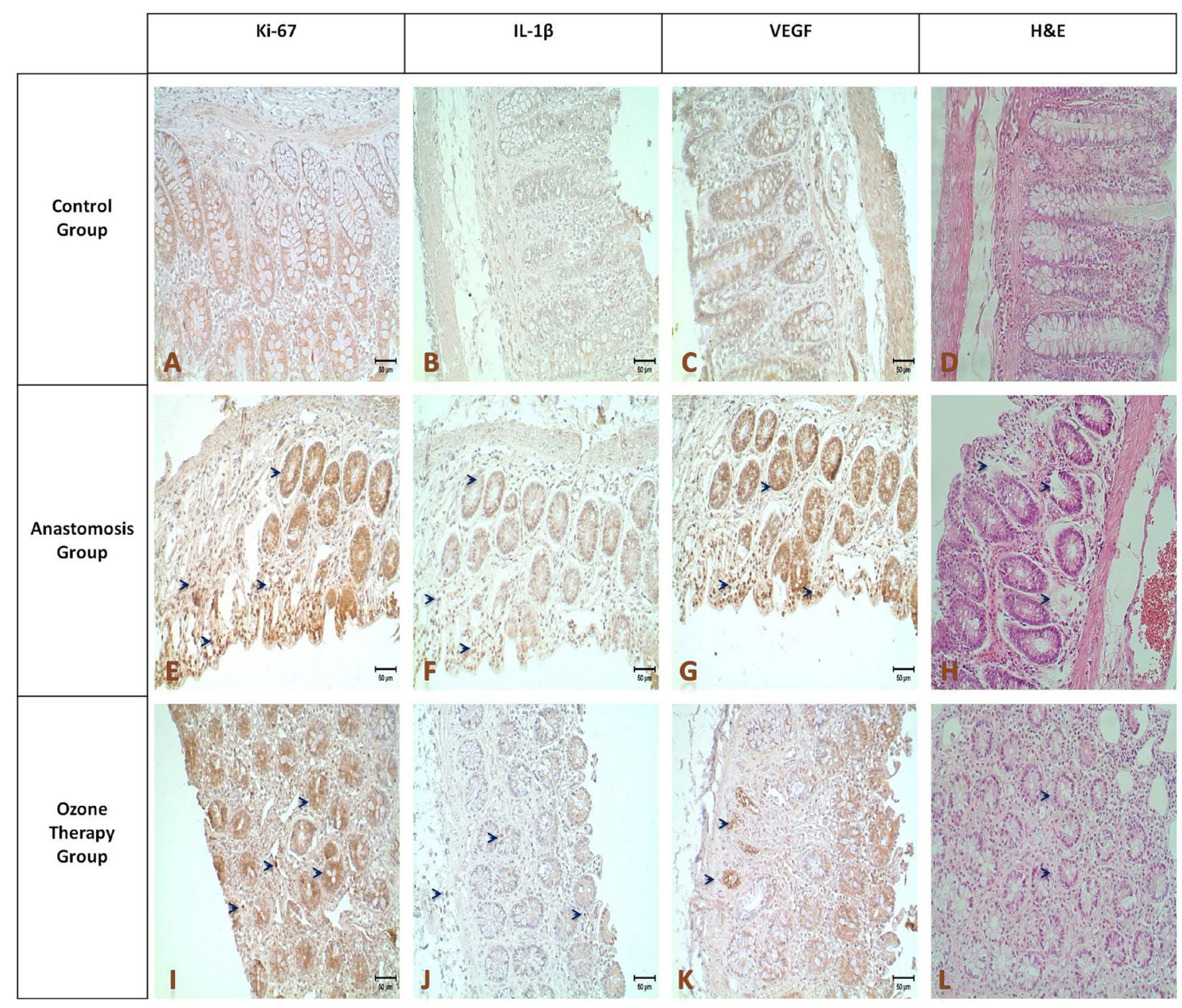

FIGURE 3 - Results of Hematoxylin-eosin staining (A,E,I,x20), after surgery despite the departure from the connective tissue in the group with anastomosis, glandular structures were largely protected (E), Ki-67, IL-1 $\beta$, the VEGF immunostaining density at the anastomosis group (F-H; arrows) was increased compared to controls (B-D), while in the group treated with ozone therapy a decrease back into control staining intensities were shown $(\mathrm{J}-\mathrm{L})$. 
The difference of the immunohistochemical staining intensity at the anastomosis group, when compared with the control and ozone therapy group. Ki-67, VEGF and IL1- $\beta$ was found
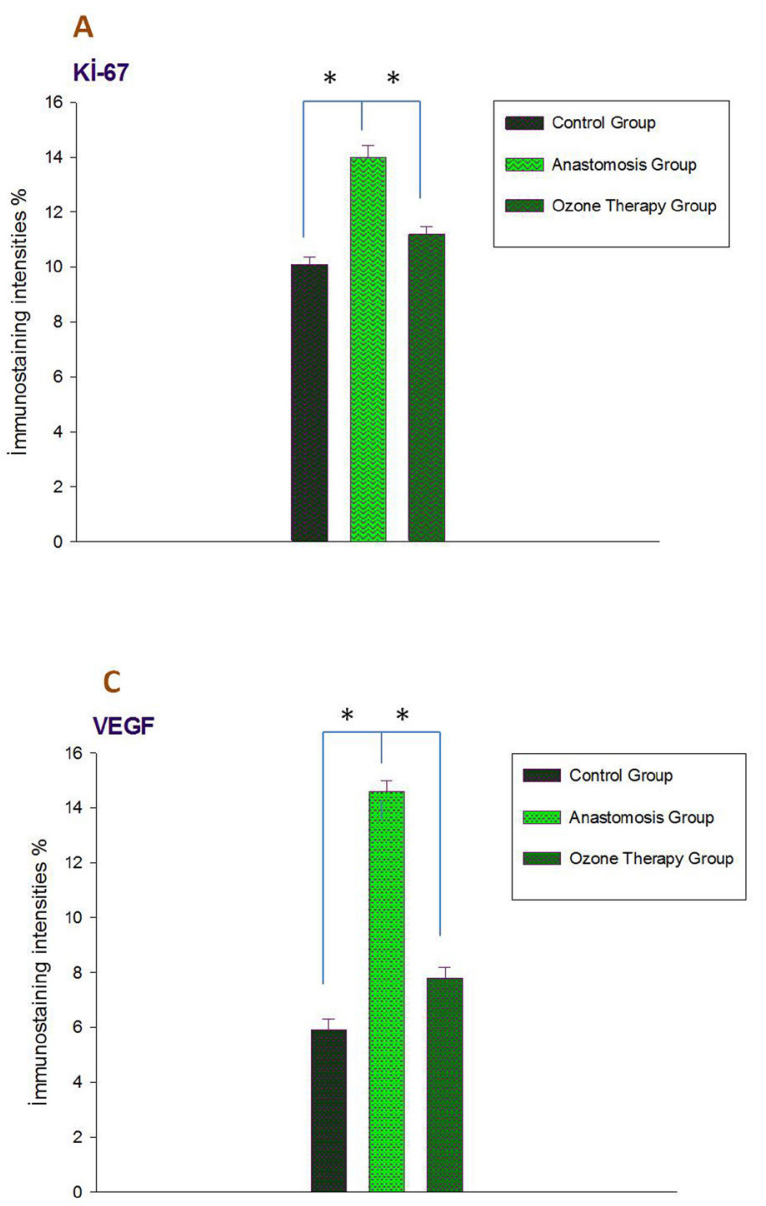

statistically significant $(\mathrm{p}<0.05)$, while the difference between ozone therapy group and control group was not significant (Figure 4).

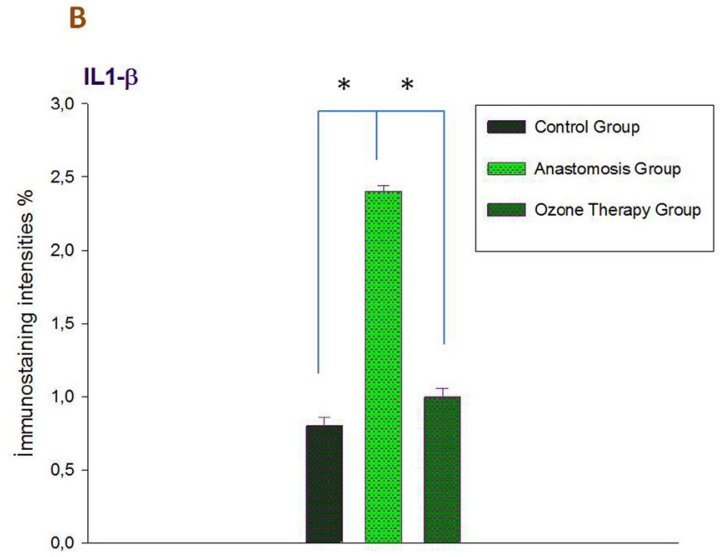

FIGURE 4 - A: Ki-67. B: IL-1ß. C: VEGF. Comparison of immunohistochemical staining intensities between the control, anastomosis and ozone therapy groups.

\section{Discussion}

One of the most common complications of gastrointestinal operations is anastomotic leaks, which are associated with high morbidity and mortality rates. The anastomotic leak rate is reported at $10 \%$ to $20 \%{ }^{9}$.

Anastomotic strength with maintenance of luminal integrity is a fundamental necessity for a successful outcome of gastrointestinal surgery. Performing a primary anastomosis in a contaminated field is thought to be associated with a failure to heal, anastomotic dehiscence, and peritoneal soilage from gastrointestinal anastomoses. Various agents have been investigated to ameliorate these effects of peritonitis on colonic anastomoses. All of these agents aiming to reduce ischemia including hyperbaric oxygen, glucan, erythropoietin, bosentan, growth hormone, and $\mathrm{H}_{2}$ antagonists like famotidine ${ }^{10-15}$.

In this study, we demonstrated an elevated protective effect of OT on colonic anastomoses in the presence of peritonitis. We evaluated bursting pressures and histopathology to measure the anastomotic healing process.

Ozone therapy blocks harmful effects of sepsis-induced injury on collagen synthesis during anastomotic wound healing. This therapy probably exerts its beneficial effects by improving antioxidant mechanisms, increasing tissue oxygenation, and promoting the production of various growth factors. In conclusion, ozone therapy has benefits on anastomotic healing of the colon in 
the presence of peritonitis. These effects can be attributed to its anti-inflammatory and antioxidative properties. Better outcomes might have been obtained if OT had been applied immediately after the operation.

According to literature search, this is the first study investigating the effect of colonic anastomosis healing with medical ozone administration at experimental peritonitis in rats. Findings from our study revealed that colonic wound healig ameliorated by intraperitoneal medical ozone administration, while with antioxidant effect the ozone theraphy prevented the lipid peroxidation and neutrophil infiltration of the rat colonic tissues. The decreasing on tissue MDA levels and MPO activities revealed that ozone theraphy prevented anastomosis integrity from oxidative stress. Also ozone theraphy was significantly improved the changes on colonic tissue caused by peritonitis in rats by decreasing the plasma cytokines.

A controlled number and dose of ozone treatments conferred protection against different physiopathological processes mediated by ROS was reported ${ }^{16}$.

In a previous study it was reported that ozone exposure altered the levels of inflammatory cytokines, such as tumor necrosis factor ${ }^{17}$, transforming growth factor ${ }^{18}$, interferon ${ }^{19}$ and interleukin $^{20}$. In our study systemic inflammatory response indicators; plasma TNF- $\alpha$ and IL-1 $\beta$ levels were also found increased due to peritonitis but decreased by ozone theraphy.

Lipid peroxidation by free oxygen radicals is an important causes of destruction and oxidative damage to cell membranes these containing unsaturated fatty acids, nucleic acids and proteins. The decreasing on tissue MDA levels revealed that ozone theraphy prevented colonic tissue from oxidative damage.

The free oxygen radicals trigger the leukocytes accumulation in tissue and activate neutrophils to secrete enzymes leading to further tissue damage ${ }^{21}$. Therefore, an enzyme secreted by neutrophils MPO play role in oxidant production ${ }^{22}$. In our study MPO activity which is an index of polimorphonuclear leukocyte infiltration and accumulation was found increased. Increased activities of MPO indicate that contributes negatively to anastomosis healing at peritonitis in rats. MPO activity was found decreased at intraperitoneal ozone theraphy.

As an indicator of wound healing bursting pressures is performed ${ }^{23}$. Mechanical parameters reflecting the growing anastomotic strength of a colonic anastomosis can be revealed by measuring $\mathrm{BP}^{24}$. In the presence of peritonitis in rats the protective effect of ozone theraphy supported by the turning back of the burst pressure levels into control group.
By shifting the oxyhaemoglobin curve into the right, ozone theraphy increased oxygenation of the tissues. $\mathrm{H}_{2} \mathrm{O}_{2}$ formed by the OT causes the production of many growth factors, especially $\mathrm{VEGF}^{25}$. In the current study, we evaluated VEGF expression and according to the histopathological results we found a statisticaly significant difference on immunostaining densities of Ki-67, VEGF and IL1- $\beta$ between the control-anastomosis groups and anastomosis-ozone therapy group.

One of the limitations of the study is having no antibiotic application.

In our study as a result intraperitoneal ozone theraphy in peritonitis model was significantly reduced the plasma TNF- $\alpha$ and IL-1 $\beta$ levels, MDA levels and MPO activity, and also ameliorated the histological changes in tissue.

\section{Conclusions}

After a surgical anastomosis ozone therapy may contribute to tissue healing by affecting the proliferation and the vascularization at the tissue. As well as, we conclude that the impact of ozone therapy is thought to be associated with a reduction in the level of IL- $1 \beta$.

\section{References}

1. Khalili TM, Navarro RA, Middleton Y, Margulies DR. Early postoperative enteral feeding increases anastomotic strength in a peritonitis model. Am J Surg. 2001 Dec;182(6):621-4. PMID: 11839327.

2. Reijnen MM, de Man BM, Hendriks T, Postma VA, Meis JF, van Goor H. Hyaluronic acid-based agents do not affect anastomotic strength in the rat colon, in either the presence or absence of bacterial peritonitis. Br J Surg. 2000 Sep;87(9):1222-8. PMID: 10971432.

3. Bulynin VI, Glukhov AA. Treatment of peritonitis using ozone and hydropressive technology. Khirurgiia (Mosk). 1999;(7):9-11. PMID: 10459177.

4. Zamora Z, González R, Guanche D, Merino N, Menéndez S, Hernández F, Alonso Y, Schulz S. Ozonized sunflower oil reduces oxidative damage induced by indomethacin in rat gastric mucosa. Inflamm Res. 2008 Jan;57(1):39-43. doi:10.1007/s00011-007-70341 .

5. Knoch HG, Klug W. Ozone-oxygen therapy in proctology. Ter Arkh. 1990;62(2):93-8. PMID: 2336632.

6. Buege JA, Aust SD. Microsomal lipid peroxidation. Methods Enzymol. 1978;52:302-10. PMID: 672633.

7. Bradford MM. A rapid and sensitive method for the quantitation of microgram quantities of protein utilizing the principle of protein-dye binding. Anal Biochem. 1976 May 7;72:248-54. PMID: 942051.

8. Hillegass LM, Griswold DE, Brickson B, Albrightson-Winslow C. Assessment of myeloperoxidase activity in whole rat kidney. J Pharmacol Methods. 1990 Dec;24(4):285-95. PMID: 1963456.

9. Phillips JD, Kim CS, Fonkalsrud EW, Zeng H, Dindar H. Effects of chronic corticosteroids and vitamin A on the healing of intestinal anastomoses. Am J Surg. 1992 Jan;163(1):71-7. PMID: 1733376. 
10. Inan A, Sen M, Sürgit O, Ergin M, Bozer M. Effects of the histamine $\mathrm{H} 2$ receptor antagonist famotidine on the healing of colonic anastomosis in rats. Clinics (Sao Paulo). 2009;64(6):567-70. PMID: 19578661

11. Di Paolo N, Bocci V, Gaggiotti E. Ozone therapy. Int J Artif Organs. 2004 Mar;27(3):168-75. Review. PMID: 15112882.

12. Moran M, Ozmen MM, Duzgun AP, Gok R, Renda N, Seckin S, Coskun F. The effect of erythropoietin on healing of obstructive vs nonobstructive left colonic anastomosis: an experimental study. World J Emerg Surg. 2007 May 15;2:13. PMID: 17502005.

13. Guzel S, Sunamak O, AS A, Celik V, Ferahman M, Nuri MM, Gazioglu E, Atukeren P, Mutlu O. Effects of hyperbaric oxygen and Pgg-glucan on ischemic colon anastomosis. World J Gastroenterol. 2006 Mar 7;12(9):1421-5. PMID: 16552813.

14. Cağlikülekçi M, Ozçay N, Oruğ T, Aydoğ G, Renda N, Atalay F. The effect of recombinant growth hormone on intestina anastomotic wound healing in rats with obstructive jaundice. Turk $\mathrm{J}$ Gastroenterol. 2002 Mar;13(1):17-23. PMID:16378269.

15. Cetinkaya Z, Esen K, Ozercan IH, Ustundag B, Ayten R, Aygen E. The effect of Bosentan on healing of colonic anastomosis. World $\mathrm{J}$ Emerg Surg. 2006 Dec 18;1:37. PMID: 17173707.

16. León OS, Menéndez S, Merino N, Castillo R, Sam S, Pérez L, Cruz E, Bocci V. Ozone oxidative preconditioning: a protection against cellular damage by free radicals. Mediators Inflamm. 1998;7(4):28994. PMID: 9792340.

17. Paulesu L, Luzzi E, Bocci V. Studies on the biological effects of ozone: 2. Induction of tumor necrosis factor (TNF-alpha) on human leucocytes. Lymphokine Cytokine Res. 1991 Oct;10(5):409-12. PMID: 1768744.

18. Bocci V. A reasonable approach for the treatment of HIV infection in the early phase with ozonetherapy (autohaemotherapy). How inflammatory cytokines may have a therapeutic role. Mediators Inflamm. 1994;3(5):315-21. PMID: 18475574.

19. Bocci V, Paulesu L. Studies on the biological effects of ozone 1. Induction of interferon gamma on human leucocytes. Haematologica. 1990 Nov-Dec;75(6):510-5. PMID: 2129118.

20. Bocci V, Valacchi G, Corradeschi F, Fanetti G. Studies on the biological effects of ozone: 8 . Effects on the total antioxidant status and on interleukin-8 production. Mediators Inflamm. 1998;7(5):3137. PMID: 9883965.

21. Jahovic N, Sener G, Cevik H, Ersoy Y, Arbak S, Yeğen BC. Amelioration of methotrexate-induced enteritis by melatonin in rats. Cell Biochem Funct. 2004 May-Jun;22(3):169-78. PMID 15124182.

22. Donnahoo KK, Meng X, Ayala A, Cain MP, Harken AH, Meldrum DR. Early kidney TNF-alpha expression mediates neutrophil infiltration and injury after renal ischemia-reperfusion. Am J Physiol. 1999 Sep;277(3 Pt 2):R922-9. PMID: 10484513.

23. Teke Z, Aytekin FO, Aydin C, Kabay B, Yenisey C, Sacar S, Simsek NG, Tekin K. Effects of pyrrolidine dithiocarbamate on healing of colonic anastomoses in the cecal ligation and puncture model of intraperitoneal sepsis in rats. World J Surg. 2007 Jan;31(1):200-9. PMID: 17180567

24. Cihan AO, Bicakci U, Tander B, Rizalar R, Kandemir B, Ariturk E, Bernay F. Effects of intraperitoneal nitroglycerin on the strength and healing attitude of anastomosis of rat intestines with ischemiareperfusion injury. Afr J Paediatr Surg. 2011 May-Aug;8(2):206-10. doi: 10.4103/0189-6725.86064.

25. Tandara AA, Mustoe TA. Oxygen in wound healing--more than a nutrient. World J Surg. 2004 Mar;28(3):294-300. PMID: 14961188

\section{Acknowledgement}

To Dr. Başar Şenyüz for ozone supply from Ozonklinik Antalya Turkey.

\section{Correspondence:}

Tuğrul Çakır

Antalya Taining and Research Hospital

Transplantation and General Surgery Department

070100, Antalya, Turkey

Phone: $+902422494400-3381$

Gsm: +90 5057323505

Fax: +902422494462

tugrul-cakir@hotmail.com

Received: Oct 16, 2015

Review: Dec 17, 2015

Accepted: Jan 19, 2016

Conflict of interest: none

Financial source: none

${ }^{1}$ Research performed at Research Laboratory, Akdeniz University of Medicine, Antalya, Turkey. 